\title{
Enterotoxigenic Escherichia coli associated with infant diarrhoea in Galicia, north-western Spain
}

\author{
J. BLANCO*, E. A. GONZÁLEZ*, M. BLANCO*, J. I. GARABAL*, M. P. ALONSO*t,

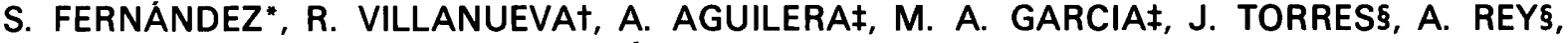 \\ W. H. JANSENT and P. A. M. GUINÉET
}

*Departamento de Microbiología y Parasitología, Facultad de Veterinaria, Universidad de Santiago, Lugo, †Sección de Bacteriología, Residencia Sanitaria Juan Canalejo, La Coruña, $\ddagger$ Servicio de Microbiología, Hospital Xeral de Galicia, Santiago de Compostela, §Unidad de Microbiología, Hospital Xeral, Lugo, Spain, and TDepartment of Bacteriology, National Institute of Public Health and Environmental Protection, Bilthoven, The Netherlands

\begin{abstract}
Summary. To assess the role of enterotoxigenic Escherichia coli (ETEC) in infantile diarrhoea, 482 children with diarrhoea and 103 healthy controls, from three localities of Galicia, northwestern Spain, were investigated between 1985 and 1988. Rotavirus $(37 \cdot 3 \%)$ and Salmonella spp. $(12.8 \%)$ were the most common causal agents, followed by ETEC $(3.9 \%)$, Campylobacter jejuni $(2.3 \%)$, Shigella spp. $(0.9 \%)$ and Yersinia enterocolitica $(0.5 \%)$. ETEC were significantly more frequently isolated from children with diarrhoea who were under 1 month of age $(26.5 \%)$ than from older diarrhoeic children $(2.2 \%)(\mathrm{p}<0.001)$ or from healthy children who were under 1 month of age $(0 \%)(p<0 \cdot 05)$. Among children who harboured ETEC, five of the nine children under 1 month of age developed diarrhoea in hospital, whereas none of the 10 children over 1 month of age did so. Seventeen ETEC isolates produced heat-stable enterotoxin (STa) only, four produced only heat-labile enterotoxin (LT), and two produced both toxins. Colonisation factor antigens CFA/I and CFA/II were detected in $11(55.0 \%)$ of the 20 ETEC isolates that remained enterotoxigenic after maintenance in the laboratory. Most ETEC isolates belonged to serotypes $0153: \mathrm{K}-: \mathrm{H} 45$ (nine $\mathrm{STa}^{+} \mathrm{CFA} / \mathrm{I}^{+}$isolates), $\mathrm{O} 27: \mathrm{K}-: \mathrm{H} 7$ (three $\mathrm{STa}^{+}$isolates) or $\mathrm{O} 6: \mathrm{K} 15: \mathrm{H} 16$ (two $\mathrm{LT}^{+} \mathrm{STa}^{+} \mathrm{CFA} / \mathrm{II}^{+}$isolates). Our results suggest that ETEC constitute an important cause of neonatal diarrhoea in this part of Spain.
\end{abstract}

\section{Introduction}

Enterotoxigenic Escherichia coli (ETEC) are responsible for $20-50 \%$ of cases of endemic diarrhoea in adults and children in countries with poor environmental hygiene and in travellers to these regions. ${ }^{1-5}$ In contrast, ETEC have been rarely associated with endemic diarrhoea in developed countries, ${ }^{6-10}$ although occasional outbreaks have been reported in North America ${ }^{11}$ and Europe. ${ }^{12-14}$

ETEC cause diarrhoea in man through the elaboration of a heat-labile (LT) and a heat-stable (STa) enterotoxin or both. ${ }^{15}$ For diarrhoea to result, ETEC must colonise the small intestine, and adhesive fimbriae such as colonisation factor antigens CFA/I and CFA/II promote attachment of bacteria to epithelial cells of the small intestine. ${ }^{15-18} \mathrm{CFA} / \mathrm{I}$ and CFA/II confer a relatively high degree of surface hydrophobicity to bacteria and are also responsible for mannose-resistant haemagglutination (MRHA) of certain types of erythrocyte. ${ }^{15-20} \mathrm{CFA} / \mathrm{I}$ and CFA/II,

Received 12 Sept. 1990; revised version accepted 19 Dec. 1990.

Correspondence should be sent to Professor J. Blanco. as well as LT and STa, are encoded by plasmids. ${ }^{16,21}$ Although many different serotypes have been described amongst ETEC, most strains belong to serotypes $\mathrm{O} 6: \mathrm{K} 15: \mathrm{H} 16, \quad \mathrm{O}: \mathrm{K} 40: \mathrm{H} 9, \quad \mathrm{O} 15: \mathrm{H} 11$, O25:K 7:H42, O25:K98:H-, O78:H11, O78:H12 and $\mathrm{O} 149: \mathrm{H}_{10} \mathrm{.}^{22-24}$

We have studied the role of ETEC in infants and young children with diarrhoea from three hospitals in Galicia, north-western Spain.

\section{Materials and methods}

\section{Children}

Stool specimens were obtained from 482 children with diarrhoea (patients) and from 103 healthy children (controls) between July 1985 and January 1988. Only children under 3 years of age were examined. Faecal samples from children with diarrhoea were collected from 109 outpatients and 373 inpatients in three hospitals in different towns of Galicia: Residencia Sanitaria Juan Canalejo (La Coruña), Hospital Xeral de Galicia (Santiago de 
Compostela), and Hospital Xeral (Lugo). These three towns are approximately $100 \mathrm{~km}$ apart. Infants developing diarrhoea after admission to hospital and subjects who had received antimicrobial treatment for the current illness were not excluded.

\section{Microbiological methods}

Fresh stool samples were cultured for bacterial enteropathogens, including E. coli, Salmonella, Shigella, Campylobacter and Yersinia spp., by standard methods; ${ }^{25} 134$ stools were also investigated for rotavirus with a commercial slide Rota-kit (BioMérieux, France) or a Rotazyme II kit (Abbot, USA). A single sample was taken from each child and three to five $E$. coli colonies isolated from each sample were examined for enterotoxin production.

\section{Enterotoxin assays}

LT production was determined by the Vero cell assay $^{26}$ and STa by the infant mouse test. ${ }^{27}$ For detection of STa and LT, bacteria were grown for $20 \mathrm{~h}$ in Tryptone Soya Broth (Oxoid) at $37^{\circ} \mathrm{C}$ (with shaking at $200 \mathrm{rpm})$ and centrifuged $(6000 \mathrm{~g})$ for $30 \mathrm{~min}$ at $4^{\circ} \mathrm{C}$; the supernates were filtered through $0 \cdot 22-\mu \mathrm{m}$ membrane filters.

\section{Detection of $C F A / I$ and $C F A / I I$}

ETEC isolates were inoculated into Mueller-Hinton Broth (Difco) and incubated at $37^{\circ} \mathrm{C}$ for 5 days until a definite pellicle was formed. From this pellicle, bacteria were inoculated on to casamino acid-yeast extract agar (CFA agar) plates ${ }^{16}$ and incubated at $37^{\circ} \mathrm{C}$ for $18 \mathrm{~h}$. Bacteria grown on CFA agar were examined for CFA/I and CFA/II by an improved staphylococcal co-agglutination test with adsorbed specific anti-CFA/I and anti-CFA/II rabbit sera. ${ }^{12}$

\section{Haemagglutination and hydrophobicity}

Tests for MRHA and mannose-sensitive haemagglutination (MSHA) were done by the rocked-tile method with human (blood groups $\mathrm{A}$ and $\mathrm{O}$ ), calf, guinea-pig, adult chicken, sheep and pig erythrocytes as previously described. ${ }^{28}$ Isolates were grouped according to their MRHA patterns in six MRHA types (I-VI). ${ }^{28}$ Bacterial surface hydrophobicity was determined by the improved salt aggregation test (ISAT) ${ }^{20}$ For these tests, bacteria were grown in batch culture in Mueller-Hinton Broth at $37^{\circ} \mathrm{C}$ for 5 days and the pellicle formed was plated on $\mathrm{CFA}^{16}$ and Minca-Is ${ }^{29}$ solid media and incubated at $37^{\circ} \mathrm{C}$ for $18 \mathrm{~h}$.

\section{Serotyping}

The presence of $\mathrm{O}, \mathrm{K}$ and $\mathrm{H}$ antigens was determined as previously described ${ }^{30}$ with all available
$\mathrm{O}(\mathrm{O} 1-\mathrm{O} 167)$ and $\mathrm{H}(\mathrm{H} 1-\mathrm{H} 56)$ antisera, and $\mathrm{O}: \mathrm{K}$ antisera against the $\mathrm{K}$ antigens usually associated with each $\mathrm{O}$ antigen.

\section{Antibiotic resistance patterns}

ETEC strains were tested for antibiotic resistance by the disk diffusion method. ${ }^{31}$ Antibiotics tested were: amikacin, co-amoxiclav, ampicillin, cefotaxime, cefoxitin, cephalothin, chloramphenicol, gentamicin, kanamycin, nalidixic acid, neomycin, nitrofurantoin, polymyxin B, streptomycin, sulphadiazine, tetracycline, tobramycin and co-trimoxazole.

\section{Control strains}

Reference $E$. coli strains used as positive and negative controls were: $\mathrm{m} 452-\mathrm{C}_{1}$ and $\mathrm{m} 633-\mathrm{C}_{1}$ $\left(\mathrm{O} 63: \mathrm{K}-: \mathrm{H}-, \mathrm{LT}^{+}, \mathrm{STa}^{+}, \mathrm{CFA} / \mathrm{I}^{+}\right), \mathrm{PB} 176$ and B2C (O6: $\left.\mathrm{H}_{16}, \mathrm{LT}^{+}, \mathrm{STa}^{+}, \mathrm{CFA} / \mathrm{II}^{+}\right)$, and $\mathrm{K} 12-185$ (non-toxigenic strain).

\section{Statistical analysis}

Results were compared by the $\chi^{2}$ test with Yates's correction for continuity.

\section{Results}

\section{Frequency of isolation of enteropathogens}

ETEC were isolated from $19(3.9 \%)$ of 482 children with diarrhoea and from $1(1.0 \%)$ of 103 controls $\left(\chi^{2}\right.$ $=1 \cdot 46, \mathrm{p}<0 \cdot 3$; not significant). However, ETEC were isolated significantly more frequently from children with diarrhoea who were under 1 month of age than from diseased children older than 1 month $\left(\chi^{2}=42 \cdot 84\right.$, $\mathrm{p}<0.001)$ or from healthy children under 1 month of age $\left(\chi^{2}=5 \cdot 11, p<0.05\right)$ (table I). The isolation rate of ETEC was higher in inpatients ( 18 of $373 ; 4.8 \%$ ) than in outpatients ( 1 of $109 ; 0.9 \%$ ), but this difference was not significant $\left(\chi^{2}=2 \cdot 45, \mathrm{p}<0 \cdot 2\right)$. Among children who harboured ETEC, five of the nine children under 1 month of age developed diarrhoea while in hospital, whereas none of 10 children older than 1 month of age did so.

Rotavirus was the most frequently identified enteric pathogen, accounting for $37.3 \%$ of the cases, followed by Salmonella spp. $(12 \cdot 8 \%)$, ETEC $(3.9 \%), C$. jejuni $(2.3 \%)$, Shigella spp. $(0.9 \%)$ and $Y$. enterocolitica $(0.5 \%)$ (table II). The isolation rates for enteropathogens other than ETEC did not differ significantly among different age groups (fig. 1). The incidence of Salmonella spp. and ETEC was higher during warm months, whereas rotavirus predominated during the cold months (fig. 2). 
Table I. Frequency of ETEC in children with diarrhoea and in healthy children of different age groups

\begin{tabular}{|c|c|c|c|c|c|}
\hline \multirow{3}{*}{$\begin{array}{l}\text { Age group } \\
\text { (months) }\end{array}$} & \multicolumn{5}{|c|}{ Number of children with ETEC strains/number investigated $(\%)$} \\
\hline & \multicolumn{4}{|c|}{ Children with diarrhoea from } & \multirow{2}{*}{ Healthy controls } \\
\hline & La Coruña & Santiago & Lugo & Total & \\
\hline$<1$ & $3 / 10(30 \cdot 0)$ & $3 / 11(27 \cdot 3)$ & $3 / 13(23 \cdot 1)$ & $9 / 34(26 \cdot 5)$ & $0 / 22$ \\
\hline $1-5$ & $0 / 60$ & $0 / 27$ & $1 / 31 \quad(3 \cdot 2)$ & $1 / 118(0.8)$ & $0 / 22$ \\
\hline 6-11 & $2 / 52 \quad(3.8)$ & $1 / 24 \quad(4 \cdot 2)$ & $0 / 26$ & $3 / 102(2.9)$ & $1 / 28 \quad(3 \cdot 6)$ \\
\hline $12-23$ & $3 / 64 \quad(4 \cdot 7)$ & $1 / 61 \quad(1.6)$ & $0 / 25$ & $4 / 150(2 \cdot 7)$ & $0 / 20$ \\
\hline $24-35$ & $2 / 27(7 \cdot 4)$ & $0 / 40$ & $0 / 11$ & $2 / 78(2 \cdot 6)$ & $0 / 11$ \\
\hline Total & $10 / 213(4 \cdot 7)$ & $5 / 163(3 \cdot 1)$ & $4 / 106(3.8)$ & $19 / 482(3 \cdot 9)$ & $1 / 103(1 \cdot 0)$ \\
\hline
\end{tabular}

Table II. Frequency of isolation of various enteropathogenic micro-organisms in children with diarrhoea

\begin{tabular}{llrlr}
\hline & \multicolumn{3}{c}{ Number (\%) } & of children from \\
\cline { 2 - 5 } Enteropathogen & \multicolumn{2}{c}{$\begin{array}{c}\text { La Coruña } \\
(\mathrm{n}=213)\end{array}$} & \multicolumn{2}{c}{$\begin{array}{c}\text { Lugo } \\
(\mathrm{n}=106)\end{array}$} \\
\hline ETEC & 10 & $(4 \cdot 7)$ & 4 & $(3 \cdot 8)$ \\
Salmonella spp. & 28 & $(13 \cdot 1)$ & 13 & $(12 \cdot 3)$ \\
Shigella spp. & 3 & $(1 \cdot 4)$ & 0 & \\
$\begin{array}{l}\text { C. jejuni } \\
\text { Y. enterocolitica }\end{array}$ & 5 & $(2 \cdot 3)$ & NT & \\
Rotavirus $\dagger$ & 1 & $(0 \cdot 5)$ & NT \\
& $18 / 50(36 \cdot 0)$ & $32 / 84(38 \cdot 1)$ \\
\hline
\end{tabular}

NT, not tested.

* S. enteritidis (38 isolates) and S. typhimurium (three isolates).

† Only 134 patients were examined for rotavirus; results show the number found to be positive/number examined.

\section{Clinical findings in ETEC diarrhoea}

Severity of disease ranged from mild to severe; $94.7 \%$ had a watery diarrhoea, but only $31.6 \%$ were febrile; vomiting occurred in $63.2 \%$ and $42.1 \%$ became dehydrated. Persistence of diarrhoea ranged from 3 to 12 days (mean 5 days). All infants with ETEC

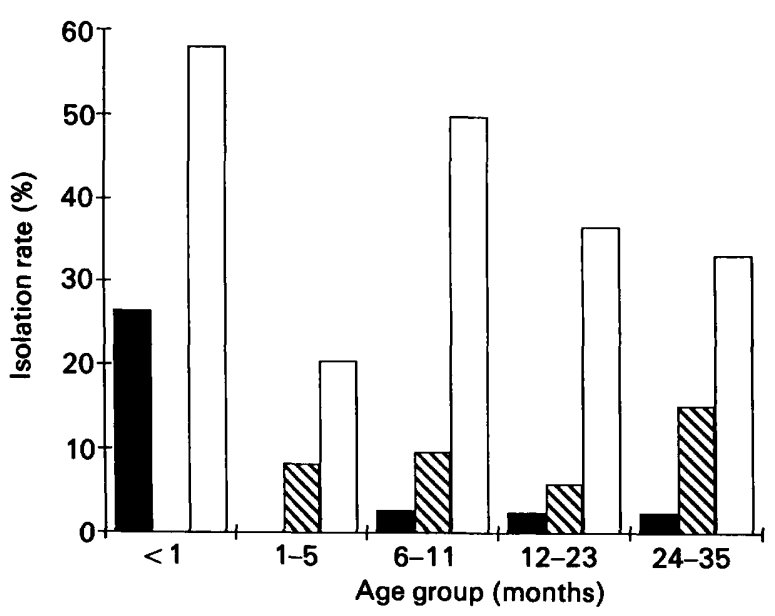

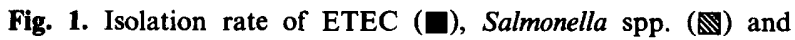
rotavirus $(\square)$ in various age groups of patients.

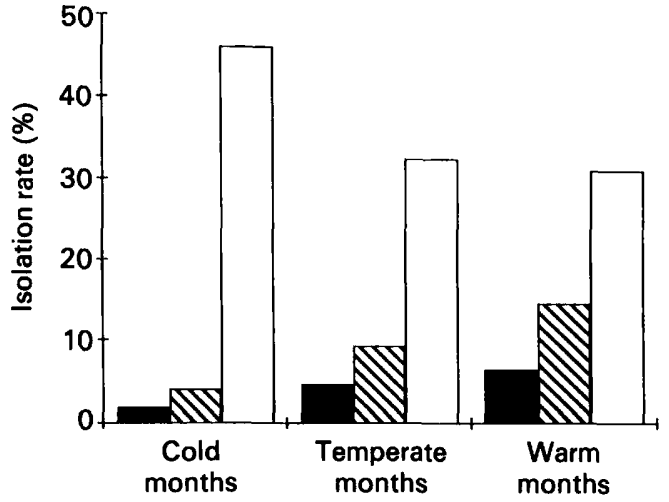

Fig. 2. Incidence of ETEC ( $)$, Salmonella spp. ( $)$ and rotavirus ( $\square$ ) by season. Cold months: Nov.-March; temperate months: April, May, Sept. and Oct.; warm months: June-Aug.

diarrhoea recovered after treatment. Nevertheless, after 5 days at home, one child was admitted to hospital and died 4 days later with an umbilical cord infection and gastro-enteritis. Blood and urine culture performed 4 days before death were negative, but faecal culture was not performed during the second period of hospitalisation.

\section{Abundance and characteristics of ETEC strains}

A total of 64 ETEC colonies were isolated from 19 children with diarrhoea. ETEC colonies were predominant in $13(68.4 \%)$ of the 19 positive samples. In 16 samples, all ETEC colonies isolated showed identical characteristics; in two samples two types of ETEC were detected and in one sample three different ETEC were observed. Characteristics of the 23 ETEC isolates are summarised in table III. Of these isolates, 17 were $\mathrm{STa}^{+}$, two $\mathrm{LT}^{+} \mathrm{STa}^{+}$and four $\mathrm{LT}^{+}$. However, three isolates (LD73b, LD76a and LD76b) lost their enterotoxic activity during maintenance in the laboratory.

CFA/I or CFA/II was detected in $11(55.0 \%)$ of the $20 \mathrm{ETEC}$ isolates that still showed enterotoxic activity after maintenance in the laboratory (table IV). CFA/ I was found in nine $(64.3 \%)$ of $14 \mathrm{STa}^{+}$isolates; CFA/ II was found in the two $(100 \%) \mathrm{LT}^{+} \mathrm{STa}^{+}$isolates; and no isolate that produced LT only expressed either colonisation factor. Most ETEC belonged to serotypes 
Table III. Characteristics of ETEC isolates from children with diarrhoea

\begin{tabular}{|c|c|c|c|c|c|c|c|c|}
\hline \multirow{2}{*}{$\begin{array}{c}\text { Isolate } \\
\text { no. }\end{array}$} & \multirow{2}{*}{ Serotype } & \multirow{2}{*}{ Toxins } & \multirow{2}{*}{$\begin{array}{l}\text { Colonisation } \\
\text { factors }\end{array}$} & \multicolumn{2}{|c|}{ Haemagglutination* } & \multicolumn{2}{|c|}{ Hydrophobicity $†$} & \multirow{2}{*}{$\begin{array}{l}\text { Antibiotic } \\
\text { resistance }\end{array}$} \\
\hline & & & & $\begin{array}{l}\text { CFA } \\
\text { agar }\end{array}$ & $\begin{array}{l}\text { Minca-Is } \\
\text { medium }\end{array}$ & $\begin{array}{l}\text { CFA } \\
\text { agar }\end{array}$ & $\begin{array}{l}\text { Minca-Is } \\
\text { medium }\end{array}$ & \\
\hline CD20b & $08: K(A) ?$ & LT & $\ldots$ & MRHA-VI MSHA & MRHA-VI MSHA & $>2 \cdot 0$ & $>2 \cdot 0$ & $\mathrm{AxCCCx}$ \\
\hline CD49a & $09: \mathbf{K}(\mathrm{A}) ?$ & LT & $\ldots$ & $\ldots$ & $\ldots$ & AA & AA & None \\
\hline CD68a & $\mathrm{O} 25: \mathrm{K} ?$ & LT & $\ldots$ & MSHA & MSHA & $2 \cdot 0$ & $2 \cdot 0$ & None \\
\hline $\mathrm{SD} 25 \mathrm{a}$ & $\mathrm{O} 71: \mathrm{K}-$ & LT & $\cdots$ & MRHA-IVb MSHA & MRHA-IVb MSHA & $\mathbf{A A}$ & AA & $\begin{array}{l}\text { Ap Sm Nm Km Tc } \\
\text { Sd }\end{array}$ \\
\hline LD102b & O6:K15:H16 & LT STa & CFA/II & MRHA-II & MRHA-II & 0.4 & 0.4 & None \\
\hline LD105a & $\mathrm{O} 6: \mathrm{K} 15: \mathrm{H} 16$ & LT STa & CFA/II & MRHA-II & $\ldots$ & 0.4 & $>2 \cdot 0$ & None \\
\hline CD5a & $\mathrm{O} 27: \mathrm{K}-: \mathrm{H} 7$ & STa & $\ldots$ & MSHA & MRHA-VI MSHA & 0.4 & $0 \cdot 4$ & None \\
\hline SD52a & $\mathrm{O} 27: \mathrm{K}-: \mathrm{H} 7$ & STa & $\ldots$ & MSHA & MRHA-VI MSHA & $0 \cdot 4$ & 0.4 & None \\
\hline CD15a & $\mathrm{O} 27: \mathrm{K}-: \mathrm{H} 7$ & STa & $\ldots$ & MSHA & MRHA-VI MSHA & $0 \cdot 4$ & 0.4 & Ap Sm Sd \\
\hline CD68b & $\mathrm{O} 153: \mathrm{K}-: \mathrm{H} 45$ & STa & CFA/I & MRHA-Ia & MRHA-Ib & 0.06 & $0 \cdot 1$ & Ap Sm Nm Km Sd \\
\hline SD53a & O153:K - :H45 & STa & CFA/I & MRHA-Ia & MRHA-Ia & $0 \cdot 06$ & 0.06 & 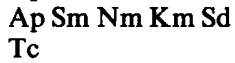 \\
\hline SD72a & O153:K - :H45 & STa & CFA/I & MRHA-Ia & MRHA-Ia & 0.06 & 0.06 & $\begin{array}{l}\text { Ap Sm Nm Km Sd } \\
\text { Tc }\end{array}$ \\
\hline CD22d & $\mathrm{O} 153: \mathrm{K}-: \mathrm{H} 45$ & STa & CFA/I & MRHA-Ia & MRHA-Ib & 0.06 & $0 \cdot 06$ & Ap Sm Sd Tc \\
\hline CD69a & O153:K - : H45 & STa & CFA/I & MRHA-Ia & MRHA-Ib & 0.06 & 0.06 & Ap Sm Sd \\
\hline CD79a & O153:K - :H45 & STa & CFA/I & MRHA-Ia & MRHA-Ib & 0.06 & 0.06 & Ap Sm Sd \\
\hline CD80c & O153:K - :H45 & STa & CFA/I & MRHA-Ia MSHA & MRHA-Ib MSHA & 0.06 & 0.06 & Ap Sm Sd \\
\hline CD99a & O153:K - :H45 & STa & CFA/I & MRHA-Ia MSHA & MRHA-Ia MSHA & 0.06 & 0.06 & Ap Sm Sd \\
\hline SD165b & O153:K $-:$ H45 & STa & CFA/I & MRHA-Ia & MRHA-Ia & 0.06 & 0.06 & Ap Sm Sd \\
\hline CD68c & NT & STa & $\ldots$ & $\ldots$ & $\ldots$ & AA & $>2 \cdot 0$ & $\mathrm{Sd}$ \\
\hline LD73c & NT & STa & $\ldots$ & MSHA & MSHA & AA & AA & Sm Sd Tc \\
\hline LD73b $\ddagger$ & $\mathrm{O} 24: \mathrm{K} ?: \mathrm{H} 15$ & STa & $\ldots$ & MSHA & MSHA & $>2.0$ & AA & $\mathrm{Sm} \mathrm{Sd} \mathrm{Tc}$ \\
\hline LD76a & O89:K - :H15 & STa & $\ldots$ & MSHA & MSHA & $1 \cdot 0$ & $1 \cdot 0$ & None \\
\hline LD76b $\ddagger$ & NT & STa & $\ldots$ & MSHA & MSHA & 1.4 & 1.4 & None \\
\hline
\end{tabular}

LT, heat-labile toxin; STa, heat-stable toxin; CFA, colonisation factor antigen; MRHA, mannose-resistant haemagglutination; MSHA, mannose-sensitive haemagglutination; AA, autoagglutinating; NT, not tested; Ap, ampicillin; AxC, co-amoxiclav; C, chloramphenicol; $\mathrm{Cx}$, cefoxitin; Sm, streptomycin; Nm, neomycin; Km, kanamycin; Tc, tetracycline; Sd, sulphadiazine.

* MRHA haemagglutination types: Ia, MRHA with human A and O, bovine, and adult chicken erythrocytes; Ib, MRHA with human A and $\mathrm{O}$, bovine, adult chicken, and pig erythrocytes; II, MRHA with calf and adult chicken erythrocytes; IVb, MRHA with human A and $\mathrm{O}$, and pig erythrocytes; VI, MRHA negative with human erythrocytes and MRHA variable with the remaining five erythrocyte species. ${ }^{28}$ $E$. coli CD20b MRHA VI ${ }^{+}$showed haemagglutination with pig erythrocytes only, whereas MRHA VI ${ }^{+}$isolates of serotype O27:K $-: \mathbf{H}_{7}$ showed MRHA with calf and sheep erythrocytes.

+ Minimal molar ammonium sulphate concentration in which bacteria aggregated in the improved salt aggregation test (ISAT).

$\ddagger$ Enterotoxic activity lost during laboratory culture.

O153:K - : $\mathrm{H} 45$ (nine $\mathrm{STa}^{+}$isolates), O27:K - :H7 (three $\mathrm{STa}^{+}$isolates) and $\mathrm{O} 6: \mathrm{K} 15: \mathrm{H} 16$ (two $\mathrm{LT}^{+}$ $\mathrm{STa}^{+}$isolates) (table III). All isolates of serotype O153: $\mathrm{K}-: \mathrm{H} 45$ were $\mathrm{CFA} / \mathrm{I}^{+}$and the two isolates of serotype $\mathrm{O} 6: \mathrm{K} 15: \mathrm{H} 16$ were $\mathrm{CFA} / \mathrm{II}^{+}$. CFA/I ${ }^{+}$isolates showed a high level of bacterial surface hydrophobicity, aggregating in $0.06 \mathrm{M}$ ammonium sulphate, when grown either on CFA agar or on Minca-Is medium. CFA $/ \mathrm{I}^{+}$isolates grown on CFA agar showed MRHA characteristic of CFA/I: MRHA with human $A$ and $O$, bovine and adult chicken erythrocytes.

Table IV. Relationship between enterotoxin production and the presence of CFA/I and CFA/II in ETEC isolates

\begin{tabular}{|c|c|c|c|}
\hline \multirow{2}{*}{$\begin{array}{r}\text { Enterotoxin } \\
\text { produced }\end{array}$} & \multicolumn{3}{|c|}{ Number $(\%)$ of isolates } \\
\hline & tested & CFA $/ I^{+}$ & $\mathrm{CFA} / \mathrm{II}^{+}$ \\
\hline $\begin{array}{ll}\text { LT } & \\
\text { LT } & \text { STa } \\
& \text { STa }\end{array}$ & $\begin{array}{r}4 \\
2 \\
14\end{array}$ & $\begin{array}{l}0 \\
0 \\
9(64 \cdot 3)\end{array}$ & $\begin{array}{l}0 \\
2(100) \\
0\end{array}$ \\
\hline Total & 20 & $9(45 \cdot 0)$ & $2(10 \cdot 0)$ \\
\hline
\end{tabular}

However, when they were grown in Minca-Is medium, some of the $\mathrm{CFA} / \mathrm{I}^{+}$isolates also agglutinated pig erythrocytes in the presence of mannose. CFA/ $\mathrm{II}^{+}$ isolates expressed a significant level of bacterial surface hydrophobicity, aggregating in $0.4 \mathrm{M}$ ammonium sulphate, and showed MRHA with bovine and adult chicken erythrocytes. Enterotoxigenic isolates of serotype $\mathrm{O} 27: \mathrm{K}-: \mathrm{H} 7$ were $\mathrm{CFA} / \mathrm{I}^{-}, \mathrm{CFA} / \mathrm{II}^{-}$, but, like CFA/ $/ \mathrm{II}^{+}$isolates, they were moderately hydrophobic ( $0.4 \mathrm{M}$ ammonium sulphate) and showed mannose-resistant haemagglutination. ETEC belonging to serotype $\mathrm{O} 27: \mathrm{K}-: \mathrm{H} 7$ expressed MRHA with calf and sheep erythrocytes when grown on Minca-Is medium, but not on CFA (table III).

Of the 23 ETEC isolates $15(65.2 \%)$ were resistant to at least one of the antibiotics tested (table III).

\section{Discussion}

These results show that ETEC is a frequent cause of diarrhoea in children younger than 1 month in Galicia. In infants below the age of 1 month, ETEC strains were isolated more frequently from children 
with diarrhoea than from controls and significant differences were observed between the incidence of ETEC in infants under 1 month of age and in older infants. Among the children under 1 month of age who developed ETEC infections, about half developed diarrhoea in hospital. This interesting result is in keeping with several reports of nosocomial outbreaks of ETEC affecting neonates in hospitals in different parts of Spain. ${ }^{12,13}$

The isolation rate of ETEC (3.9\%) in this study was lower than the $10.5 \%$ found by Cǒbeljić et al. ${ }^{32}$ in Yugoslavia and the $5.9 \%$ found by Escribano et al. ${ }^{13}$ in Valencia on the Mediterranean coast of Spain. However, the rate was higher than that observed in other studies carried out in Spain, ${ }^{7,33}$ in other European countries ${ }^{6,10}$ and in North America. ${ }^{8,9}$

Rotavirus was the most frequently identified enteropathogen, followed by Salmonella spp. and ETEC; as in other studies ${ }^{2,33,34}$ infections by ETEC and Salmonella spp. had seasonal peaks in the warmer months, whereas infections by rotavirus were more frequent during colder months.

Reports from other geographical areas indicate that $\mathrm{LT}^{+} \mathrm{STa}^{+}$and $\mathrm{STa}^{+}$strains, which usually express CFA/I or CFA/II, are isolated mainly from ill children, whereas $\mathrm{LT}^{+}$strains, normally without colonisation factors, have been found in similar proportions in sick and healthy children., ${ }^{3,4}$ In our study, CFA/I and CFA/II were produced by $55 \%$ of the ETEC isolates. This incidence is higher than the $18-41 \%$ reported in most published studies. ${ }^{17-19,35,36}$ However, similar ${ }^{34}$ or higher ${ }^{1,37}$ incidences have been reported from other parts of the world. In this study, CFA/I was detected in most $\mathrm{STa}^{+}$isolates and CFA/II in the two $\mathrm{LT}^{+} \mathrm{STa}^{+}$isolates, but no isolate producing $\mathrm{LT}$ alone expressed colonisation factors.

Most ETEC detected in this study belonged to a few serotypes and expressed CFA/I or CFA/II. ETEC of serotype $027: \mathrm{K}-: \mathrm{H} 7$ did not express CFA/I or CFA/ II, but were hydrophobic and showed MRHA with calf and sheep erythrocytes when grown on Minca-Is medium. We think that the mannose-resistant haemagglutinin expressed by $\mathrm{O} 27: \mathrm{K}-: \mathrm{H} 7 \mathrm{ETEC}$ may represent a new putative colonisation factor, unrelated to others that have recently been described, which lack MRHA, or in which it is expressed with human and calf erythrocytes. ${ }^{15,17,18}$ Further studies are necessary to establish the role of the mannose-resistant haemagglutinin expressed by ETEC strains of $\mathrm{O} 27: \mathrm{K}-: \mathrm{H} 7$

E. coli $\mathrm{O} 153: \mathrm{K}-: \mathrm{H} 45$ strains producing STa and CFA/I were the most common ETEC isolates in this study. Similar strains have been found to be responsible for three outbreaks of nosocomial diarrhoea in neonates in two hospitals in Madrid ${ }^{12}$ and in a hospital in Valencia ${ }^{13}$ in recent years. ETEC strains of this serotype have also been found to be the most common ETEC isolates in Chile, ${ }^{1}$ but have been detected only occasionally in Italy, ${ }^{13}$ Germany, ${ }^{38}$ Liberia, ${ }^{13}$ the Central African Republic, ${ }^{39}$ Somalia $^{40}$ and Thai- land. ${ }^{21}$ Of the other ETEC isolates in this study, serotype $\mathrm{O}: \mathrm{K} 15: \mathrm{H} 16$ is commonly reported from different parts of world, ${ }^{1,8,22-24,36}$ and serotype $\mathrm{O} 27: \mathrm{K}-: \mathrm{H} 7$ has been detected previously in Somalia, ${ }^{40}$ Kenya $^{36}$ and Thailand ${ }^{22}$ as well as in travellers with diarrhoea who visited asian countries. ${ }^{24}$ However, E. coli $\mathrm{O} 27$ : K - :H7 was not found commonly among ETEC isolates in others countries.

Our results suggest that ETEC strains, mainly $\mathrm{STa}^{+}$ $\mathrm{CFA} / \mathrm{I}^{+}$belonging to serotype $\mathrm{O} 153: \mathrm{K}-: \mathrm{H} 45$, are an important cause of neonatal diarrhoea among infants in Galicia. We recommend routine screening for ETEC in Spanish clinical microbiology laboratories, especially in stools from newborn children under 1 month of age and in outbreaks of diarrhoea. Most ETEC strains could be detected by means of simple and rapid slide agglutination or co-agglutination tests with specific anti-CFA/I and anti-CFA/II sera, and another serum against the putative new colonisation factor associated with ETEC strains of O27:K $-: \mathrm{H} 7$. ETEC strains may be the most important cause of diarrhoea in Spain after rotavirus and Salmonella spp.

This paper is dedicated to the memory of Dr Piet A. M. Guinée an eminent scientist, an excellent collaborator and a very good friend. Our grateful thanks to students of the Veterinary Medicine Faculty of Lugo for their help during the sampling of healthy children. This work was supported by grants from the Fondo de Investigaciones Sanitarias de la Seguridad Social (FISSs 85/1182), Xunta de Galicia (84301188 and 8430489) and Dirección General de Investigación Científica y Técnica (DGICYT PM89-0142). M.B. J.I.G. and S.F. thank the Ministerio de Educación y Ciencia of Spain and the Xunta de Galicia for research fellowships.

\section{References}

1. Agüero ME, Reyes L, Prado V, Ørskov I, Ørskov F, Cabello FC. Enterotoxigenic Escherichia coli in a population of infants with diarrhea in Chile. J Clin Microbiol 1985; 22: 576-581.

2. Black RE, Merson MH, Rahman ASMM et al. A two-year study of bacterial, viral, and parasitic agents associated with diarrhea in rural Bangladesh. J Infect Dis $1980 ; 142$ : 660-664.

3. Cravioto A, Reyes RE, Ortega R, Fernández G, Hernández R, López D. Prospective study of diarrhoeal disease in cohort of rural Mexican children: incidence and isolated pathogens during the first two years of life. Epidemiol Infect 1988 ; 101 : 123-134.

4. Kim K-H, Suh I-S, Kim JM, Kim CW, Cho Y-J. Etiology of childhood diarrhea in Korea. $J$ Clin Microbiol 1989; 27 : 1192-1196.

5. Sack RB, Froehlich JL, Zulich AW et al. Prophylactic doxycycline for travellers' diarrhea. Results of a prospective doubleblind study of Peace Corps volunteers in Morocco. Gastroenterology 1979; 76: 1368-1373.

6. Bäck E, Möllby R, Kaijser B. Relative importance, seasonal variation, $\mathrm{O}$-and $\mathrm{K}$-antigens of enterotoxigenic Escherichia coli: a three-and-a-half year review in Sweden. $J$ Infect $1980 ; 2$ : 302-315.

7. Blanco J, González EA, Bernárdez I, Varela BR. Enterotoxigenic and enteropathogenic Escherichia coli in Galicia (north-west Spain). Med Microbiol Immunol 1983; 172: 165-169.

8. Brunton J, Hinde D, Langston C, Gross R, Rowe B, Gurwith M. Enterotoxigenic Escherichia coli in central Canada. $J$ Clin Microbiol 1980; 11 : 343-348. 
9. Echeverria P, Blacklow NR, Smith DH. Role of heat-labile toxigenic Escherichia coli and reovirus-like agent in diarrhoea in Boston children. Lancet 1975; 2: 1113-1116.

10. Mäki M, Vesikari T, Grönroos P. Enterotoxigenic and invasive Escherichia coli as causes of childhood diarrhoea in Finland. Acta Paediatr Scand 1980; 69: 219-224.

11. Wachsmuth K, DeBoy J, Birkness K, Sack D, Wells J. Genetic transfer of antimicrobial resistance and enterotoxigenicity among Escherichia coli strains. Antimicrob Agents Chemother $1983 ; 23: 278-283$.

12. Blanco J, González EA, Blanco $\mathbf{M}$ et al. Prevalence of enterotoxigenic Escherichia coli strains in outbreaks and sporadic cases of diarrhoea in Spain. Eur J Clin Microbiol Infect Dis $1989 ; 8$ : 396-400.

13. Escribano A, Ørskov I, Ørskov F, Borras R. Enterotoxigenic Escherichia coli O153: $\mathrm{H} 45$ from an outbreak of diarrhoea in Spain. Med Microbiol Immunol 1987; 176: 241-244.

14. Rowe B, Gross RJ, Scotland SM, Wright AE, Shillom GN, Hunter NJ. Outbreak of infantile enteritis caused by enterotoxigenic Escherichia coli O6.H16. J Clin Pathol $1978 ; 31: 217-219$.

15. Levine MM. Escherichia coli that cause diarrhea: enterotoxigenic, enteropathogenic, enteroinvasive, enterohemorrhagic, and enteroadherent. J Infect Dis 1987; 155: 377389.

16. Evans DG, Silver RP, Evans DJ, Chase DG, Gorbach SL. Plasmid-controlled colonization factor associated with virulence in Escherichia coli enterotoxigenic for humans. Infect Immun 1975; 12: 656-667.

17. Honda T, Wetprasit N, Arita M, Miwatani T. Production and characterization of monoclonal antibodies to a pilus colonization factor (colonization factor antigen III) of human enterotoxigenic Escherichia coli. Infect Immun 1989; 57: $3452-3457$

18. Thomas LV, Cravioto A, Scotland SM, Rowe B. New fimbrial antigenic type (E8775) that may represent a colonization factor in enterotoxigenic Escherichia coli in humans. Infect Immun 1982; 35: 1119-1124.

19. Blanco J, González EA, Anadón R. Colonization antigens and haemagglutination patterns of human Escherichia coli. Eur J Clin Microbiol 1985; 4: 316-326.

20. González EA, Blanco J, Baloda SB, Wadström T. Relative cell surface hydrophobicity of Escherichia coli strains with various recognized fimbrial antigens and without recognized fimbriae. Zentralbl Bakteriol Mikrobiol Hyg [A] $1988 ; 269: 218-236$.

21. Echeverria P, Seriwatana J, Taylor DN et al. Plasmids coding for colonization factor antigens I and II, heat-labile enterotoxin, and heat-stable enterotoxin A2 in Escherichia coli. Infect Immun 1986; 51 : 626-630.

22. Echeverria P, Ørskov F, Ørskov I, Plianbangchang D. Serotypes of enterotoxigenic Escherichia coli in Thailand and the Philippines. Infect Immun 1982; 36: 851-856.

23. Ørskov I, Ørskov F. Special O:K:H serotypes among enterotoxigenic Escherichia coli strains from diarrhea in adults and children. Med Microbiol Immunol 1977; 163: 99-110.

24. Rowe B, Gross R, Takeda Y. Serotyping of enterotoxigenic Escherichia coli isolated from diarrheal travelers from various Asian countries. FEMS Microbiol Lett 1983; 20: 187-189.

25. Ewing WH, Edwards PR. Edwards and Ewing's identification of Enterobacteriaceae, 4th edn. New York, Elsevier Science Publishing Co. 1986.

26. Konowalchuk J, Speirs JI, Stavric S. Vero response to a cytotoxin of Escherichia coli. Infect Immun 1977; 18: 775779.

27. Dean AG, Ching Y-C, Willians RG, Harden LB. Test for Escherichia coli entertoxin using infant mice: application in a study of diarrhea in children in Honolulu. $J$ Infect Dis 1972; 125 : 407-411.

28. Blanco J, Alonso MP, González EA, Blanco M, Garabal JI. Virulence factors of bacteraemic Escherichia coli with particular reference to production of cytotoxic necrotising factor (CNF) by P-fimbriate strains. J Med Microbiol 1990; 31 : 175-183.

29. Guinée PAM, Veldkamp J, Jansen WH. Improved minca medium for the detection of K99 antigen in calf enterotoxigenic strains of Escherichia coli. Infect Immun 1977; 15: 676-678.

30. Guinée PAM, Jansen HW, Wadström T, Sellwood R. Escherichia coli associated with neonatal diarrhoea in piglets and calves. In: de Leeuw PW, Guinée PAM (eds) Laboratory diagnosis in neonatal calf and animal science, 13. The Netherlands, Martinus Nijhoff. 1981 : 126-162.

31. Barry AL, Thornsberry C. Susceptibility testing: diffusion test procedures. In: Lennette RH, Balows A, Hausler WJ, Truant JP (eds) Manual of clinical microbiology, 3rd edn. Washington, DC, American Society for Microbiology. 1980: 463-474.

32. Cǒbeljić M, Mel D, Arsić B et al. The association of enterotoxigenic and enteropathogenic Escherichia coli and other enteric pathogens with childhood diarrhoea in Yugoslavia. Epidemiol Infect 1989; 103: 53-62.

33. Velasco AC, Mateos ML, Más G, Pedraza A, Díez M, Gutiérrez A. Three-year prospective study of intestinal pathogens in Madrid, Spain. J Clin Microbiol 1984; 20 : 290-292.

34. Yam WC, Li Lung ML, Yeung CY, Tam JS, Ng MH. Escherichia coli associated with childhood diarrheas. J Clin Microbiol 1987; 25 : 2145-2149.

35. Changchawalit S, Echeverria P, Taylor DN et al. Colonization factors associated with enterotoxigenic Escherichia coli isolated in Thailand. Infect Immun 1984; 45: 525-527.

36. Levine MM, Ristaino P, Sack RB, Kaper JB, Ørskov F, Ørskov I. Colonization factor antigens I and II and type 1 somatic pili in enterotoxigenic Escherichia coli: relation to enterotoxin type. Infect Immun 1983; 39: 889-897.

37. Gotherfors L, Áhrén C, Stoll B et al. Presence of colonization factor antigens on fresh isolates of fecal Escherichia coli: a prospective study. J Infect Dis 1985; 152: 1128-1133.

38. Bockemülhl J, Wohlers B, Aleksić S et al. Incidence of sporadic infections due to enterotoxigenic Escherichia coli (ETEC) in the population of Hamburg, North Germany. Zentralbl Bakteriol Mikrobiol Hyg 1989; 272: 58-64.

39. Georges MC, Wachsmuth IK, Birkness KA, Moseley SL Georges AJ. Genetic probes for enterotoxigenic Escherichia coli isolated from childhood diarrhea in the Central Africa Republic. J Clin Microbiol 1983; 18: 199-202.

40. Caprioli A, Falbo V, Ruggeri FM, Bisicchia R, Casalino M, Donelli G. Comparison among enterotoxigenic strains of Escherichia coli isolated in Italy and Somalia. Eur $J$ Epidemiol 1988; 4: 251-255. 